\title{
Influence of picture presence in reviews on online seller product rating: Moderation role approach
}

\author{
Md Altab Hossin ${ }^{1 *}$, Yinping Mu ${ }^{1}$, Jiaming Fang ${ }^{1}$, Adasa Nkrumah Kofi Frimpong ${ }^{1}$ \\ ${ }^{1}$ School of Management and Economics, University of Electronic Science and Technology of China \\ No.2006, Xiyuan Ave, West Hi-Tech Zone, 611731, Chengdu, Sichuan, P.R.China \\ [e-mail: altabbd@163.com] \\ *Corresponding author: Md Altab Hossin
}

Received December 24, 2018; revised March 20, 2019; accepted August 4, 2019; published December 31, 2019

\begin{abstract}
Online consumer reviews (OCRs) provide product information and recommendations especially pictures in reviews depict the true information about the product. This study investigates the influence of pictured reviews on online seller (for a particular product of a seller) rating with moderating effect of price, brand type (foreign vs local), goods type (experience vs search), and brand familiarity. Multiple robust linear regression analysis with moderation interaction and quadratic effect used to explain the relationship of the explanatory variables with the criterion variable. We collected cross-sectional data from the two most renowned Chinese online shopping platforms (B2C) of total 15,621 product links. Results show that higher number of reviews with a low ratio of picture reviews response negative effect on rating, whereas the lower number of reviews with a high ratio of picture reviews response positive effect on the rating. In overall picture in the reviews improve the online seller product rating. For the moderation effect, results show that price and brand familiarity have a positive interaction effect on the relation of pictured reviews and rating whereas experience goods have less negative effect comparing search goods. Finally, local brand has less negative interaction effect comparing foreign brand to pictured reviews and rating.
\end{abstract}

Keywords: Online consumer reviews; Picture influence; Consumer behavior; Search goods; Experience goods; Moderation effect 


\section{Introduction}

In recent years, the evolvement of E-commerce is remarkable with the aid of the internet and information technology. According to report, worldwide e-commerce selling quantity touched \$2 trillion in 2018 as well as its quantity predicted to be more than twice by 2021 [1]. Adopting the ecommerce technology, consumer behavior has been changed for online shopping process. Electronic word-of-mouth (eWOM) is the key factor to motivate this consumer behavior and online consumer reviews (OCRs) are considered as an extension of eWOM which are very important for both consumer and seller. Before purchasing the goods, nowadays consumers focus on eWOM specially OCR to get the product information details from previous buyers. eWOM provides reliable and important information about the goods which is very helpful to buy goods from both online and offline. Presently it is the most active research area for academics and considered as potential source of product information to the consumers for their purchasing decision [2-4]. Consumers actively rely on the information from eWOM to buy products such as booking a hotel, movie watching, retail product etc. as well as buying their product offline. By the advantages of ecommerce and social media, consumers can review the product after purchasing the goods which are potentially helpful for the future buyer as a recommendation and trustful information reflecting their decision-making process when considering to buy the goods [5]. On the internet, OCR influences are omnipresent as a form of recommendations, review contents, and numerical ratings and consumer influenced each other by this influences [5].

In OCR, consumers usually generate two kinds of information after purchasing the goods: an overall numerical rating or individual rating of quality, service, packaging etc. and the review contents with text or text with pictures. These reviews and ratings are the most influential part of OCR and consumers can easily get the reviews and ratings of a product in order to make a purchasing decision. Rating becomes the lucid and consumer first looking for rating information while purchasing the product. In this context, online rating becomes one of the most trusted and significant sources when making online purchasing decisions and considered them as trustworthy. Nielsen [6] found that online rating considered as a second most-trusted source of brand information after recommendations from friends and family. Both manufacturers and sellers are sensitive to this rating and follow-up the rating record. Consumers willing to pay more than 20 percent higher price for excellent (5 star) rating than Good(4 star) rating which transparently shows the influence of rating on price [7]. On the other hand, review contents exert the particular feelings of consumers and are key to understand the effect of OCR by review contents [8]. However, review contents with rating have particular interaction and consumers have different sentiments while posting them together. Review contents along with text and pictures together are more symmetric since they display the true information of the product and consumer satisfaction, and reflect the rating.

Nevertheless, some researchers and practitioners investigated related domain to visual presentation as a stimuli of consumer behavior such as product image views and size [9], visual information effects [10], music and goods presentation modes [11], 3D effects [12], video effects [13], image interactivity [14], and image contexts [15]. In the context of OCR, only a few researchers have so far analyzed pictured reviews effects to the rating. In addition very few researchers investigated the influence of the pictured existence in reviews to rating relationship especially with the moderating role of product price, brand type (local brand vs. foreign brand) and goods type (search vs. experience). 
Extending the existing research towards OCR, the goal of this study is to broaden the knowledge about the influence of pictured reviews on ratings especially the moderating role to the relation of picture reviews and ratings. In this steam of research, we analyzed and presented the quadratic effect of pictured reviews and moderating role effect by deploying robust multiple linear regression analysis.

Specifically, our investigation focused on the following questions:

(1) How do the pictured reviews influence the rating?

(2) How do the price, brand and goods type (search vs experienced) interact with pictured reviews and ratings?

In the following sections, we present the literature review and hypotheses. Subsequently, we report a methodology of 2 (search goods) x 2 (experience goods) for the data analysis. Finally, we conclude by discussing the results and presenting suggested future research directions in this area.

\section{Literature review and hypotheses}

This paper focused on two strands of literature. First, it goes through online consumer reviews (OCR), an extension of electronic word of mouth (eWOM) in particular usergenerated content (UGC) such as ratings and review contents. Second, it complements studies investigating the moderating role to the relation of pictured reviews and rating in online markets for the price, brand type, and goods type.

\subsection{Online Consumer Reviews (OCR) and social proof}

OCRs are considered the most active and growing research area in the various field of ecommerce such as B2C, C2C, Hotel, Tourism, Foods, and Consultancy etc. Many researchers have actively examined the various effects of eWOM and OCR in different areas such as consumer behavior, trust, purchasing decision etc. [16-19]. OCRs are the good proxy of eWOM which greatly influencing the consumer purchasing decision and many firms use these OCRs as their new marketing tool [20]. Alike traditional advertising, information provided by sellers, third party websites, recommendations through OCRs are used as digital marketing as a form of eWOM which provides an effective and reliable source of information and influencing consumer purchasing decisions [21]. Before purchasing a product, consumers search for product information and gather relevant production information from OCRs [22]. Just after the recommendations of family and friend, OCRs can be treated as second trustful source of information for a particular product [6]. Compared to seller-generated product descriptions, OCRs which are generated by consumers are more user-friendly and describe the product usage, application, suitability, and quality [23]. OCRs not only describe the product information but also indicates seller quality. Thus, OCRs play the vital role of information to the consumers who purchase the goods for the first time. OCRs now considered as a good way for marketing, it is believed that it can reflect consumer purchasing decisions and behavior. Besides posting the product advertisement and information in online forums, social media, and ecommerce site nowadays many firms encourage their customer to diffuse their product information as a form of eWOM [17] as well as some sellers strategically applied these OCRs tools to motivate consumer purchasing decisions and preferences [16]

OCRs can help consumers, sellers, and manufacturers in various way. First, for the consumer they can express their satisfaction, disappointment and recommendation through 
OCR after purchasing the product. This expression through OCR will benefit future consumer to know about their preferred goods. Alternatively, this can benefit sellers to recover and improve service, loyalty, and product quality that brings more customer and retain regular customers [24]. Second, OCRs can be used as digital marketing tool that can facilitate seller to improve selling rate. OCRs also cultivate customer loyalty and trust that helping seller for price premium [18]. Third, information generated through OCRs reflect the consumer demand, preference, and attention which can help sellers to know customer demand and gaining a new customer, on the other hand, it can help manufacturers to improve product quality and additional features [25]. Table 1 summarizes recent important findings of OCRs.

Table 1. Summary of important findings of OCR from recent literature

\begin{tabular}{|l|l|l|}
\hline Authors & Data Source & \multicolumn{1}{|c|}{ Key Findings } \\
\hline $\begin{array}{l}\text { Chevalier and } \\
\text { Mayzlin [18] }\end{array}$ & $\begin{array}{l}\text { Amazon.com, } \\
\text { Barnesandnoble.com }\end{array}$ & $\begin{array}{l}\text { Review contents are more preferred than OCRs } \\
\text { summary statistics numbers and five-star reviews are } \\
\text { less influential than one-star review and consumer } \\
\text { read the one-star review carefully. }\end{array}$ \\
\hline Hu et al. [26] & Amazon.com & $\begin{array}{l}\text { When reading the OCRs, consumers focus on } \\
\text { reviewer reputation, reviewer expressions, and } \\
\text { emotions. }\end{array}$ \\
\hline $\begin{array}{l}\text { Zhang et al. } \\
\text { [21] }\end{array}$ & Amazon.com & $\begin{array}{l}\text { Review valence on persuasiveness is moderated by } \\
\text { the reviewed product consumption goals of a } \\
\text { consumer. }\end{array}$ \\
\hline $\begin{array}{l}\text { Mudambi and } \\
\text { Schuff [27] }\end{array}$ & Amazon.com & $\begin{array}{l}\text { Perceived helpfulness of OCRs influenced by } \\
\text { product type, review acuteness and depth. Product } \\
\text { type also moderates the review acuteness effect on } \\
\text { OCRs perceived helpfulness. }\end{array}$ \\
\hline Cao et al. [28] & CNETD & $\begin{array}{l}\text { Consumers pay more attention to semantic and } \\
\text { extreme reviews rather than basic, mixed, common } \\
\text { and fancy reviews when reading review contents. }\end{array}$ \\
\hline $\begin{array}{l}\text { Korfiatis et al. } \\
\text { [29] }\end{array}$ & Amazon.co.uk & $\begin{array}{l}\text { In the context of perceived helpfulness of OCRs, } \\
\text { review readability is more effective than its length. } \\
\text { Consumers skip lengthy and vague review contents. }\end{array}$ \\
\hline $\begin{array}{l}\text { Lee and Shin } \\
\text { [30] }\end{array}$ & $\begin{array}{l}\text { Simulation } \\
\text { experiment }\end{array}$ & $\begin{array}{l}\text { In the presence of reviewers' photo, review quality } \\
\text { significantly impacts the website evaluation. In the } \\
\text { case of product evaluation of search goods, review } \\
\text { quality has a momentous influence on the consumer } \\
\text { purchasing decision. }\end{array}$ \\
\hline $\begin{array}{l}\text { Huang et al. } \\
\text { [31] }\end{array}$ & Amazi et al. \\
\hline 32$]$ & Amazon.com, & $\begin{array}{l}\text { Characteristics of a reviewer and review messages } \\
\text { have a varying degree of impact on review } \\
\text { helpfulness. }\end{array}$ \\
\hline $\begin{array}{l}\text { Perceived helpfulness of OCR is influenced by } \\
\text { review type and a number of concepts. }\end{array}$ \\
\hline $\begin{array}{l}\text { When reading the OCRs, Americans conscious } \\
\text { about internal product features and product detail } \\
\text { information, on the other hand, Chinese aware of } \\
\text { external product features and feelings of a consumer. }\end{array}$ \\
\hline
\end{tabular}




\begin{tabular}{|l|l|l|}
\hline & & $\begin{array}{l}\text { When writing reviews, Americans directly express } \\
\text { their opinion whereas Chinese use an indirect } \\
\text { expression in their contents. }\end{array}$ \\
\hline Munzel [34] & restocritics.com & $\begin{array}{l}\text { The more identity-descriptive information is } \\
\text { disclosed about the reviewer, the more trustworthy } \\
\text { the review source will be evaluated. }\end{array}$ \\
\hline $\begin{array}{l}\text { Huang et al. } \\
\text { [35] }\end{array}$ & $\begin{array}{l}\text { Fonts used in OCRs have an effect through } \\
\text { Amanumers perceived reviewer credibility and it } \\
\text { vanishes when consumers are motivated to } \\
\text { elaborate. }\end{array}$ \\
\hline $\begin{array}{l}\text { Gavilan et al. } \\
\text { [36] }\end{array}$ & $\begin{array}{l}\text { Booking.com, } \\
\text { TripAdvisor.com }\end{array}$ & $\begin{array}{l}\text { number of reviews where consumers trust for low } \\
\text { rating with less effect of review number }\end{array}$ \\
\hline
\end{tabular}

Through the Table 1, recent literature review research and investigations show that how scholar and practitioners particularly emphasis on various elements of OCRs such as review helpfulness, review influence, review valence, review readability, review acuteness, review expressions, reviewers photo, consumer trust on review and rating, and so on. Furthermore, some researchers shown their research interest and investigated about digital product presentation such as interactive persuasion [14], image contexts [15], image size [9], 3D effects [12], video effects [13], visual and verbal information effects [37], goods presentation ways [11]. However, a very few researchers be aware of and not investigated the picture effects in the reviews to rating in the context of OCR.

\subsubsection{Form of OCRs}

In ecommerce OCRs consist of two parts: rating, an overall numerical rating or individual rating for quality, service, product information, packaging etc. submitted by the consumer after purchasing and receiving/consuming the goods; reviews, an overall review contents for each product order that received/consumed by the user. The content consists either text with emotions or textual with pictures and consumer need to handle and lookup this triad information when they buy a product online. On the contrary, consumers have different sentiments when posting the OCRs by these triad relations together. Ratings are the overall measurement of seller or product statistics which are the easiest way to understand and it represents the large quantity of information. For the consumer, it is also convenient and easy to generate rating to measure the seller, goods or service. Consumers can easily establish selection criteria for the seller/product/service such as only options over 4 in a 5 scale rating. When searching or choosing a product, consumers firstly lookup the rating summary which is readily understandable informational cue [23]. Product ratings come from the certain number of reviews and these review numbers and contents display the social proof of the product popularity as well as awareness of product or service quality and advise. 


\subsubsection{Role of consumer-generated pictures (CGPs) in OCRs}

Consumers express their feelings and shopping experience through review texts and pictures. When the consumers extremely satisfied or dissatisfied, they are more likely to express their feelings and shopping experience through OCRs [38]. Aral and Walker [39] found that future ratings are biased by prior ratings in the presence of a positive social influence of the product. When the consumers searching product information, they are likely to be biased by OCRs [19]. A recent study shows that consumers trust high rating along with the high number of reviews where consumers trust low rating with less effect of review numbers [36]. Like trust, consumers have different sentiment and situation while giving reviews. Textual reviews can sometimes be fake due to the lacking of proper evidence especially pictures. Some study conducted research on fake reviews $[34,40]$. Comparing textual reviews, picture reviews are more authentic. Since it delineates the real information of the product and purchasing evidence. Picture presence in the reviews can improve the review quality and cognitive ability (See Fig. 1A and 1B) as well as symmetric information.

Consumers can post different angle of product pictures such as usage, logistics, packaging, features, outlook design etc. as evidence of purchase, which can provide a real sense of the product and thus attracting more consumers to view the reviews carefully. Different types of application of the product can come through consumer-generated pictures (CGPs) which can attract more consumers to buy that product. With the increase of internet speed and display and memory devices nowadays online retailers and marketplaces emphasis to add pictures, videos in the OCRs. Furthermore, consumers pay more attention to CGPs as an alternative and reliable source of product application and operation. Delp and Jones [41] found that patients paid much more attention and recalled health information better when it was presented with pictures than in text alone. In the context of e-commerce, Riegelsberger et al. [42] found that after adding the employee's photo, the online sellers pre-existing reputation on perceived trustworthiness of the website increased.

Consumer behavior and experiences are explained by dual coding theory (DCT) such as verbal and visual presentations [43]. This visual representation activates imagery processing in parallel as visual stimuli to the consumer that is information encoded as a form of the picture [44]. In the context of word meaning O'Neill [45] found that imagery process plays a vital role since imagery value correlates 0.7 and concreteness value correlates 0.64 by the ease of word definition. Educational scholars also warranted the picture influence and attention in the context of the sentence and long text comprehension. Denis [46] found that picture formation and additional images are more beneficial for text comprehension as well as subjects remembering capacity with images are greater than without images. While processing the educational learning, imagery process expected to contribute better vital role [47]. Paivio [48] stated in the DCT that additional influences of imagery and verbal processing are more influential than only verbal code. Imagery systems together with concreteness are more influential to human memory due to particular organization abilities of imagery system [47, 49]. For the cognitive learning strategies program conducted by [50], imagery description considered as the key component. 


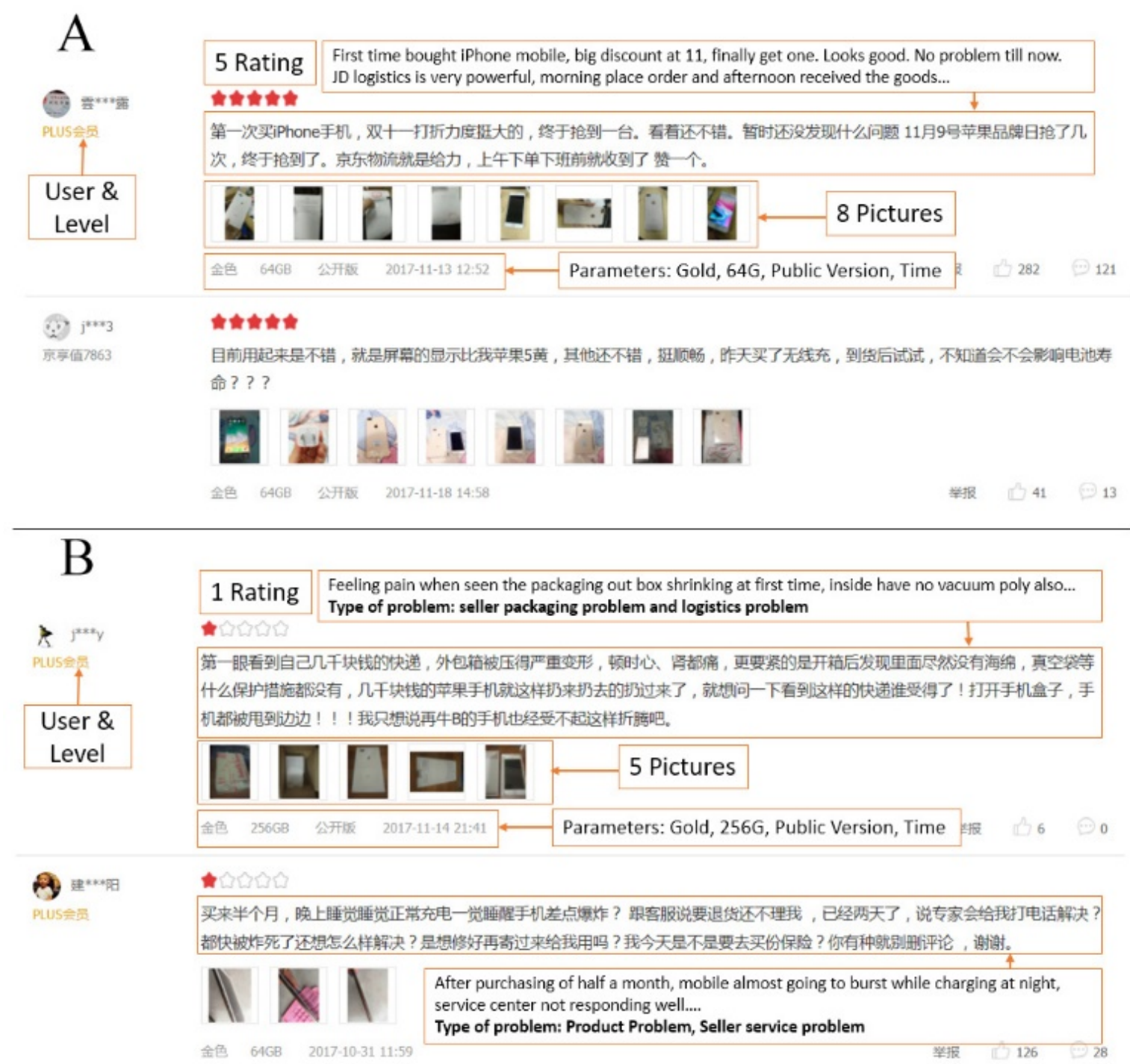

Fig. 1. Picture presence in reviews for good and bad ratings

Nevertheless, picture existence in OCR is increasing gradually with the internet speed as well as mobile device facilities. Lee and Shin [30] found that consumer review quality has a significant impact on the website evaluation only in the presence of consumer photos. A picture is worth than thousands of words and it can depict the consumer sentiment easily. Especially the picture in the reviews come from the consumer with a different perspective. Picture depicts the mode and behavior of a consumer or user. Generally, users post pictures in social media about the credits, happy life, and entertainment activities such as Facebook, Twitter, and Instagram. In this sense, consumers also post pictures when they satisfied with the product according to their expectation which bringing positive reviews. In some cases, some consumers tempt to post pictures with the bad impression for the product but in less portion because whenever they meet with bad product experience consumer will first contact with customer service and the problem may have solved prior to post the bad pictures. So posting the bad pictures in the reviews have less chance by rational. Sometimes the 
consumers in the online market just skip to post the picture when they are satisfied with the product and wait for the product evaluation. A conceptual framework about picture existence influence in reviews is shown in Fig. 2.

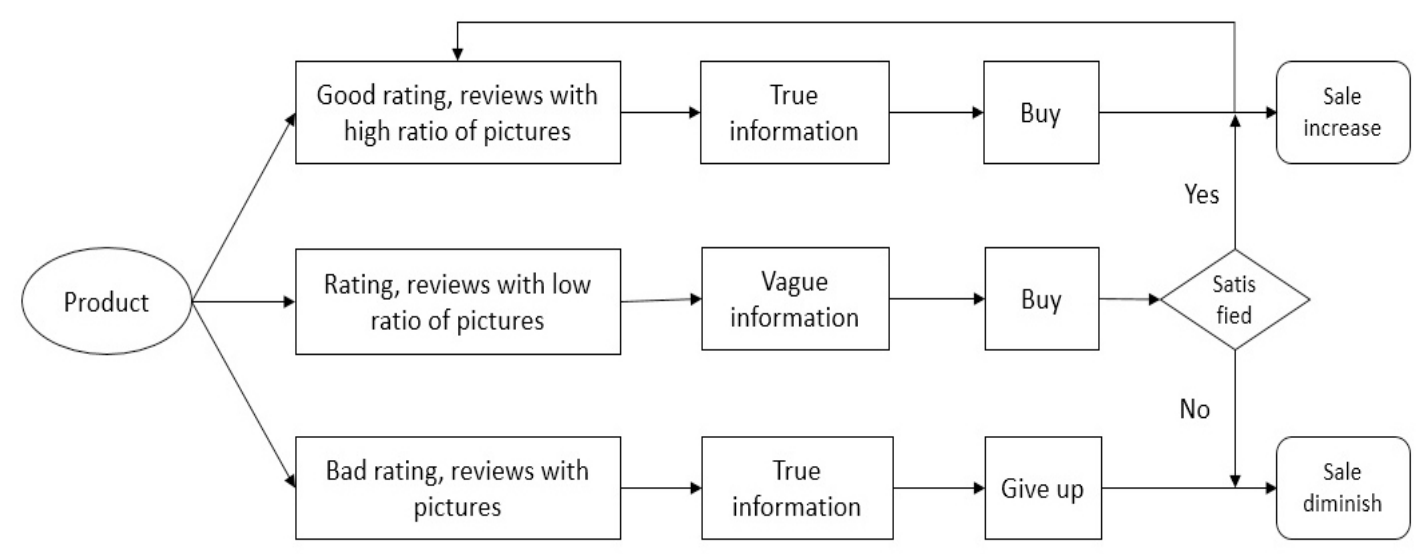

Fig. 2. Conceptual framework of picture existence influence in reviews

In the conceptual framework when a consumer buys goods after getting true information from good ratings, reviews with the high ratio of pictures, usually they will satisfy and giving more reviews consequently increasing the sales and good reviews for a particularly good product. On the contrary, mostly consumer will give up the products purchasing after getting the true information from bad ratings, reviews with pictures consequently diminishing the sales of that particular product. But when the information is vague with very fewer pictures in reviews consumer may satisfy or dissatisfy after purchasing the product. For satisfaction state, they will post good reviews, which will increase the sales and good reviews for that product. For the dissatisfaction sate, they may post bad reviews, hence inducing sales diminishing of the product. Therefore, focusing on the pictured reviews and the seller product rating relationships consider consumer sentiment and behavior, we state in the following hypothesis:

H1: Picture presence in the reviews improves the online seller product ratings

\subsection{Moderating role to the relation of pictured reviews and rating}

\subsubsection{Price role}

Price has a significant effect to OCRs for the picture existence in reviews. Consumer tends to place reviews with more pictures for the higher price with satisfaction and carefulness while they may ignore to post the picture in reviews for the low price product. On another hand, for a specific product low price tends to be lower quality bringing negative reviews. Therefore, considering the moderating role of price to the pictured reviews and rating, we state that:

H2a: Product price positively moderates the association between pictured reviews and ratings 


\subsubsection{Brand type role}

Local brands have more influence than foreign brands such as price premium, marketing, and community support. They are more familiar with the local environment, consumer behavior, and the current market situation. A consumer will support the local brand as their country brand. Local brand will take all this advantage and have good ratings with more pictures and reviews over the foreign brands. For the local brand, the seller will enhance to improve reviews with pictures to make their product more symmetric for customer expectation. On the other hand, mostly foreign brand tends to be good quality and popular brand. Hence, consumers are not much interested to post reviews and pictures as there is nothing new to demonstrate their feeling and products issues. Considering local and foreign brands effect to pictured reviews and rating, we state that:

H2b: Foreign brand more negatively moderates the association between pictured reviews and ratings than the local brand.

\subsubsection{Good type (Search and Experience) role:}

For the online shopping and marketing channel, search and experience goods classifications is the effective and popular way to explore the products [51]. Many works of literature used this classification for their analysis in the ecommerce sector. The search/experience goods differentiated based on whether consumers can evaluate the goods or attributes before purchasing [52]. When the consumer can evaluate the goods and find all the product attributes information before purchasing, then the product said to be a search goods. On the contrary, if the product attributes not known prior purchase and consumers need to consume the product in order to evaluate the goods as its quality then it is categorized to experience goods [51, 53]. The greater the product attribute and information can sense before purchasing, the more search characteristics the products fall into. On the other hand, the greater the consumer needs haptic sense and consume the goods the more the experience characteristics that the product displaying. Many researchers have employed moderating effect of goods type in OCR analysis and found that experience-related reviews are more important and valuable than attribute-based reviews because they can provide more visualized and simulated product consumption experience [54-56]. Pictures are more important for experience goods since they can depict the experience after consuming the product and consumers look more information from reviews since they cannot find enough information from seller generated information. For the experience goods, sellers also enhance to improve reviews with pictures as evidence of product quality and popularity. Subsequently, pictures in reviews tend to have positive relationships with the rating for the experience goods rather than search goods. Therefore, we hypothesize that,

H2c: Experience goods more positively moderates the association between pictured reviews and ratings than search goods

The conceptual model shown in Fig. $\mathbf{3}$ contains the major constructs necessary for testing the assumptions, such as pictured reviews, price, brand type, goods type, and brand familiarity. 


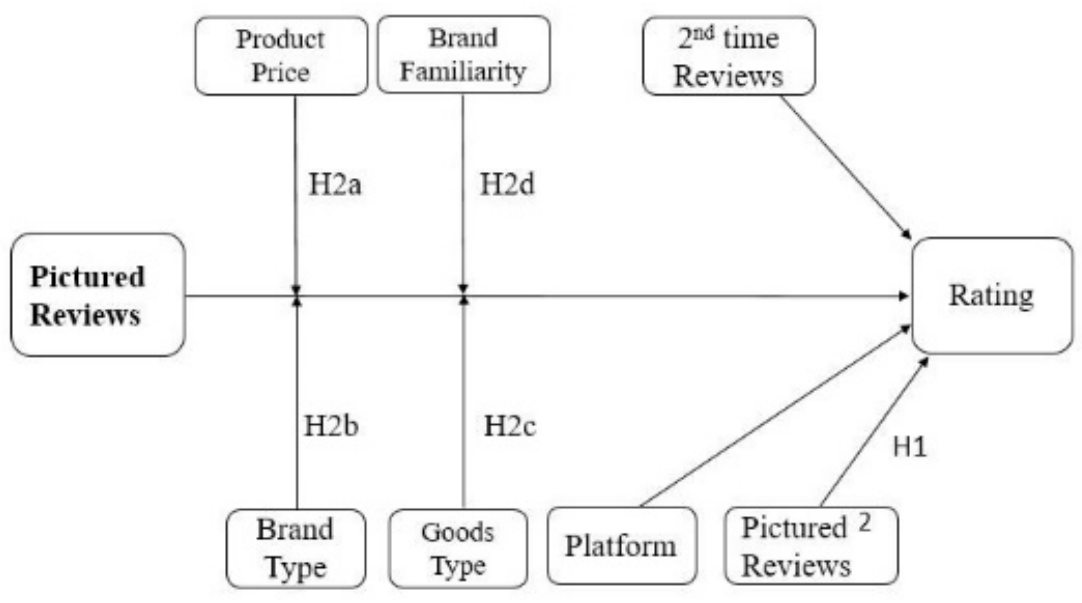

Fig. 3. Proposed theoretical framework

\subsubsection{Brand familiarity role}

Brand knowledge and familiarity affect the consumer behavior while posting the reviews. Well-known brand generally has a higher quality and positive pleasant experience to the consumer. Consumers tend to review positively for a well-known brand, because of their previous pleasant experience. In contrary, unknown brands have doubt about quality, so consumer negatively review for the bad products, in addition, unknown brands although have good quality, some consumers will not post good reviews due to unknown and doubt of the real quality of their product. Hence we state a hypothesis that,

H2d: Well-known brand more positively moderates the association between pictured reviews and ratings than not a well-known brand.

\section{Methodology}

\subsection{Data collection}

We collected 17,295 product links data from the two most renowned online marketplaces (jd.com and tmall.com) in China. Statista [57] report shown that tmall.com ranked with 56.7\% market share where jd.com ranked with 27.2\% market share for B2C online shopping market. According to [58], tmall.com secured 56.6\% market share while jd.com gained $24.7 \%$ market share in 2016 for the retail ecommerce domain in China. iResearch-2017 also predicted for gross merchandise value (GMV) about \$707.5 billion in 2016 and \$572.0 billion in 2015 respectively for China's B2C industry [58]. In 2016 "Singles Day” Alibaba including tmall.com and taobao.com raised sales volume more than $\$ 5$ billion only in the first hour of selling phase [59]. In the "618" another popular shopping day in China, jd.com had reached sales volume to \$23.7 billion from June 1, 2018 to June 18, 2018 which also counted as 37\% year over year (YOY) growth rate of jd.com [60]. Therefore, data from this two platform is the main reliable source of research in the field of B2C market. Data collected for two type of products (search and experience). For the search goods we have collected data for the laptop computer of 2960 products from jd.com, 1600 products from tmall.com [61] and mobile phone of 2768 products from jd.com, 1196 products from tmall.com [27]. For the experience goods we have collected data for the facial mask of 2983 
products from jd.com, 1368 products from tmall.com and biscuit of 2937 products from jd.com, 1483 products from tmall.com. According to [52] anticipation, these mobile and laptop be a good example of search goods whereas biscuit and facial mask be a good example of experience goods since a user needs to consume these type of goods to get their experience. We created questionnaires for each category of product to collect brand familiarity score. Finally, all datasets combine for cross-validation.

\subsection{Sample selection}

In the datasets, there were some duplicate products, and some products are so old and removed by the seller. Hence, we removed all the duplicate rows of data where information is incomplete. We also removed the rows with missing values such as total reviews, total pictured reviews, and price values. Some product links appeared price with -1 values also deleted from the dataset. In the second step of sampling, we have removed the datasets with total pictured reviews 0 values since we are aware to find the relation of pictured reviews with ratings. In our research, pictured reviews are the ratio of the total number of reviews that have pictures by the total number of reviews. So any proportion with 0 value of pictured reviews is out of our research scope. For the rating, we have removed the all the datasets less than 3.5 numerical rating since the 0 rating especially there is no transaction data and below 3.5 are considered as outlier datasets and in very less size of data. After sampling and data processing, we extracted total 15,621 sets of valid datasets considered to be reliable for our research scope.

\subsection{Measures}

\subsubsection{Independent and dependent variable}

Our independent variable is the pictured reviews which is the ratio of the number of reviews consist of pictures to the total number of reviews, pictured reviews $=$ number of reviews exist with pictures/total number of reviews. In both Tmall and JD pictured reviews mean the number of reviews consists of pictures which also exist in the top of the reviews section. Pictured reviews $(\mathrm{M}=0.16, \mathrm{SD}=0.18)$ considered as a main independent variable which affects the dependent variable online seller product rating $(\mathrm{M}=4.87, \mathrm{SD}=0.11)$ (see Table 2). Our collected data have two different rating measurement scale. Tmall.com rating comes with the numerical measure from 0-5 and JD.com rating comes with the numerical measure from $0-100$. To uniform both rating scale we divided JD.com rating with 20 that is similar with Tmall.com.

\subsubsection{Control Variable}

Extraneous effects are controlled by numerous variables related to review type, platform of our sample. Review type related control variable is (1) 2nd-time reviews $(\mathrm{M}=0.03, \mathrm{SD}=0.07)$ which posted by a consumer after a certain time of consuming the product with/without pictures. 2nd-time reviews also anticipated as a ratio of the number of 2nd-time reviews to the number of total reviews. Since it also has picture existence we consider this indirect effect as a control variable. Platform type related control variable is (2) platform which is a dichotomous variable where $0=\mathrm{Jd}$.com and $1=$ Tmall.com. Both platforms have a similar pattern of reviews with text and pictures, so we consider this indirect effect as the control variable. 
Table 2. Descriptive information.

\begin{tabular}{|c|c|c|c|c|c|c|c|c|}
\hline Variable & $\mathbf{N}$ & Mean & SD & \multicolumn{5}{|c|}{ Percentile } \\
\hline & & & & Min & $25 \%$ & $50 \%$ & $75 \%$ & Max \\
\hline Pictured reviews & 15,621 & 0.16 & 0.18 & 0.0 & 0.05 & 0.10 & 0.20 & 1.00 \\
\hline Pictured reviews $^{2}$ & 15,621 & 0.06 & 0.13 & 0.0 & 0.00 & 0.01 & 0.04 & 1.00 \\
\hline $2^{\text {nd }}$ time reviews & 15,621 & 0.03 & 0.07 & 0.0 & 0.00 & 0.01 & 0.03 & 1.00 \\
\hline Product price & 15,621 & 2.58 & 0.99 & -0.1 & 1.77 & 2.41 & 3.58 & 4.71 \\
\hline Brand type & 15,621 & 0.29 & 0.45 & 0.0 & 0.00 & 0.00 & 1.00 & 1.00 \\
\hline - Local & 11,155 & & & & & & & \\
\hline - $\quad$ Foreign & 4,466 & & & & & & & \\
\hline Brand Familiarity & 15,621 & 2.84 & 1.66 & 1.0 & 1.00 & 3.00 & 5.00 & 5.00 \\
\hline Goods type & 15,621 & 0.51 & 0.50 & 0 & 0 & 1 & 1 & 1 \\
\hline - Search & 7,661 & & & & & & & \\
\hline - $\quad$ Experience & 7,960 & & & & & & & \\
\hline Platform & 15,621 & 0.34 & 0.47 & 0.0 & 0.00 & 0.00 & 1.00 & 1.00 \\
\hline - JD.com & 1,0275 & & & & & & & \\
\hline - Tmall.com & 5,346 & & & & & & & \\
\hline Rating & 15,621 & 4.87 & 0.11 & 3.60 & 4.80 & 4.90 & 4.95 & 5.00 \\
\hline \multicolumn{9}{|c|}{ After centering the variable (exclude dichotomous variable) } \\
\hline Pictured reviews & 15,621 & 0.00 & 0.18 & -0.16 & -0.11 & $\begin{array}{l}- \\
0.06\end{array}$ & 0.04 & 0.84 \\
\hline Pictured reviews $^{2}$ & 15,621 & 0.03 & 0.08 & 0.00 & 0.00 & 0.01 & 0.02 & 0.70 \\
\hline $2^{\text {nd }}$ time reviews & 15,621 & -0.00 & 0.07 & -0.03 & -0.03 & $\begin{array}{l}- \\
0.02\end{array}$ & $\begin{array}{l}- \\
0.00\end{array}$ & 0.97 \\
\hline Product price & 15,621 & -0.00 & 0.99 & -2.68 & -0.81 & $\begin{array}{l}- \\
0.17\end{array}$ & 1.00 & 2.13 \\
\hline Brand Familiarity & 15,621 & 0.00 & 1.66 & -1.84 & -1.84 & 0.16 & 2.16 & 2.16 \\
\hline
\end{tabular}

\subsubsection{Moderating variable}

Moderating variables were anticipated by numerous variable related to price, product, and brands as interaction effect to the relation of pictured reviews and ratings [62]. Moderator variables are (1) product price $(\mathrm{M}=2.58, \mathrm{SD}=0.99)$. Since the price variation is very high as well vary product to product, we scale the product price by logarithm base 10 to minimize the variation effect as well as help for regression analysis; (2) goods type which is a dichotomous variable where $0=$ search goods and $1=$ experience goods; (3) brand type which is a dichotomous variable where $0=$ local brands and 1 =foreign brands; (4) brand familiarity score $(\mathrm{M}=2.84, \mathrm{SD}=1.66)$ which considered as continuous categorical variable measured on 5 Likert point scale where $1=$ strongly not well known brand and $5=$ strongly well-known brand. A questionnaire survey was conducted through wjx.cn to collect the brand knowledge data for each category of product.

We then center the continuous independent variable (IV) by subtracting the sample mean to further reduce multicollinearity between its direct and quadratic terms [63]. Descriptive information is shown in Table 2 after centering the continuous IV. Table 3 shows the correlation matrix for the variables and we find a significant correlation on pictured reviews, price, brand type, goods type, and brand familiarity as our major concern of this research. 
Table 3. Correlation matrix

\begin{tabular}{|l|l|l|l|l|l|l|l|l|l|l|}
\hline \multicolumn{2}{|l|}{ Constructs } & $\mathbf{( 1 )}$ & $\mathbf{( 2 )}$ & $\mathbf{( 3 )}$ & $\mathbf{( 4 )}$ & $\mathbf{( 5 )}$ & $\mathbf{( 6 )}$ & $\mathbf{( 7 )}$ & $\mathbf{( 8 )}$ & $\mathbf{( 9 )}$ \\
\hline 1 & Pictured reviews & 1 & & & & & & & & \\
\hline 2 & Pictured reviews & 0.93 & 1 & & & & & & & \\
\hline 3 & 2nd time reviews & 0.56 & 0.51 & 1 & & & & & & \\
\hline 4 & Product price & $\mathbf{0 . 5 7}$ & 0.43 & 0.36 & 1 & & & & & \\
\hline 5 & Brand type & $\mathbf{0 . 1 1}$ & 0.09 & 0.09 & 0.17 & 1 & & & & \\
\hline 6 & Brand Familiarity & $\mathbf{0 . 3 1}$ & 0.22 & 0.19 & 0.58 & 0.38 & 1 & & & \\
\hline 7 & Goods type & $\mathbf{- 0 . 5 0}$ & -0.37 & -0.33 & -0.86 & -0.07 & -0.55 & 1 & & \\
\hline 8 & Platform & 0.22 & 0.20 & 0.40 & 0.12 & 0.09 & 0.01 & 0.03 & 1 & \\
\hline 9 & Rating & -0.02 & 0.05 & -0.15 & -0.10 & -0.03 & -0.07 & 0.13 & -0.27 & 1 \\
\hline
\end{tabular}

\subsection{Data analysis}

Prior to regression analysis, our data were examined as follows. First, the rating was truncated below 3.5 scale, because 0 numerical rating has no transaction records, hence 0 numerical rating was unnecessary for us. In addition, below 3.5 numerical rating tends to have very low transaction records as well suspicious as an outlier. So we exclude datasets below 3.5 numerical ratings motivated by the winsorized method to reduce the potential bias caused by spurious extreme values [64]. We also excluded the 0 value of pictured reviews proportion since our main concern is to see the pictured reviews relation with the rating, any proportion with zero value of pictured reviews is out of our research scope. Second, we examined the data for influential outliers by calculating Cooks' distance [63]. Cooks' distance values were all significantly below one for each performance measure. These results indicate that our analysis is unlikely to be influenced by extreme outliers. Third, we center the continuous IV in order to improve the regression results.

Moderated multiple regression (MMR) analysis conducted using robust regression [65] technique and iteratively reweighted least squares (IRLS) method. Robust regression has great advantages over ordinary least squares (OLS) method in presence of outlier effect. Robust regression also applicable in heteroscedasticity case that comes from the large difference among size and observations due to a different category of products and variety of explanatory variable factors in our research case.

For the moderation effect to the pictured reviews and rating relationship, we use the model 2 provided by the [66]. We use pictured reviews as a main independent variable. Pictured reviews square term as a quadratic effect of pictured reviews, product price, goods type, brand type, brand familiarity as moderating role [67] to the relation of pictured reviews and numerical online seller product rating while controlling the $2^{\text {nd }}$ time reviews and platform effect to the relation. To analyze the effect from our hypothesis we using moderated multiple regression (MMR) as equation 1:

Rating $=\beta_{0}+\beta_{2}$ Pictured Reviews $+\beta_{3}$ Pictured Review ${ }^{2}+\beta_{4}$ 2nd time reviews $+\beta_{5}$ Product Price

$$
\begin{aligned}
& +\beta_{6} \text { Brand Type }+\beta_{6} \text { Brand Familiarity }+\beta_{8} \text { Good Type }+\beta_{9} \text { Platform } \\
& +\beta_{10} \text { Pictured reviews } x \text { Product price }+\beta_{11} \text { Pictured reviews } x \text { Brand type } \\
& +\beta_{12} \text { Pictured reviews } x \text { Goods type }+\beta_{13} \text { Pictured reviews } x \text { Brand Familiarity }
\end{aligned}
$$




\section{Results}

Multiple robust regression analysis using the Iteratively Reweighted Least Squares (IRLS) method was conducted in R. Table 4 shows our regression analysis results as a test for the independent, control, and moderator variable to the dependent variable. Significant Fstatistics values of $F(12,15608)=215.9, p=0.000$ and $R 2$ values of $14.2 \%$ suggest that our models explain a significant portion of the variation of each performance measure. Results also show low standard error (SE). Since our sample size $>30$, we use two-tailed z test for pvalue which also significant in overall.

Table 4. Regression Analysis Results

\begin{tabular}{|l|l|l|l|l|}
\hline Variable & Coeff & SE & $\mathbf{z}$ & $\mathbf{P}>|\mathbf{z}|$ \\
\hline Constant & 4.8587 & 0.002 & 2665.025 & 0.000 \\
\hline Pictured reviews & -0.1332 & 0.016 & -8.244 & $\mathbf{0 . 0 0 0}$ \\
\hline Pictured reviews2 & 0.2525 & 0.018 & 13.763 & $\mathbf{0 . 0 0 0}$ \\
\hline 2nd time reviews & -0.1031 & 0.014 & -7.265 & 0.000 \\
\hline Product price & 0.0234 & 0.002 & 13.664 & 0.000 \\
\hline Brand type & -0.0037 & 0.002 & -2.137 & 0.033 \\
\hline Brand Familiarity & -0.0017 & 0.001 & -2.941 & 0.003 \\
\hline Goods type & 0.0612 & 0.003 & 17.877 & 0.000 \\
\hline Platform & -0.0758 & 0.002 & -44.315 & 0.000 \\
\hline $\begin{array}{l}\text { Pictured reviews } x \\
\text { Product price }\end{array}$ & 0.1181 & 0.013 & 8.983 & $\mathbf{0 . 0 0 0}$ \\
\hline $\begin{array}{l}\text { Pictured reviews } x \\
\text { Brand type }\end{array}$ & -0.0222 & 0.010 & -2.188 & $\mathbf{0 . 0 2 9}$ \\
\hline $\begin{array}{l}\text { Pictured reviews } x \\
\text { Goods type }\end{array}$ & 0.1250 & 0.031 & 4.098 & $\mathbf{0 . 0 0 0}$ \\
\hline $\begin{array}{l}\text { Pictured reviews } x \\
\text { Brand Familiarity }\end{array}$ & 0.0087 & 0.003 & 2.568 & $\mathbf{0 . 0 1 0}$ \\
\hline $\mathrm{R}^{2}=14.2 \%, \mathrm{~F}(12,15608)=215.9, p=0.000, \mathrm{~N}=15,621$ & \\
\hline
\end{tabular}

\subsection{Quadratic effect}

Results show the negative associations between the pictured reviews and the seller product rating $(\beta=-0.1332, \mathrm{p}<0.01)$, but the quadratic term of the pictured reviews (pictured reviews ${ }^{2}$ ) show the expected positive associations with the seller product rating $(\beta=0.2525$, $\mathrm{p}<0.01$ ). Result shows the decreasing effect for low pictured reviews to the rating whereas increase effect for high pictured reviews to the rating (see Fig. 4). The decrease and increase effect is caused by together with reviews number (effect 1 ) and the ratio of pictured reviews (effect 2). 


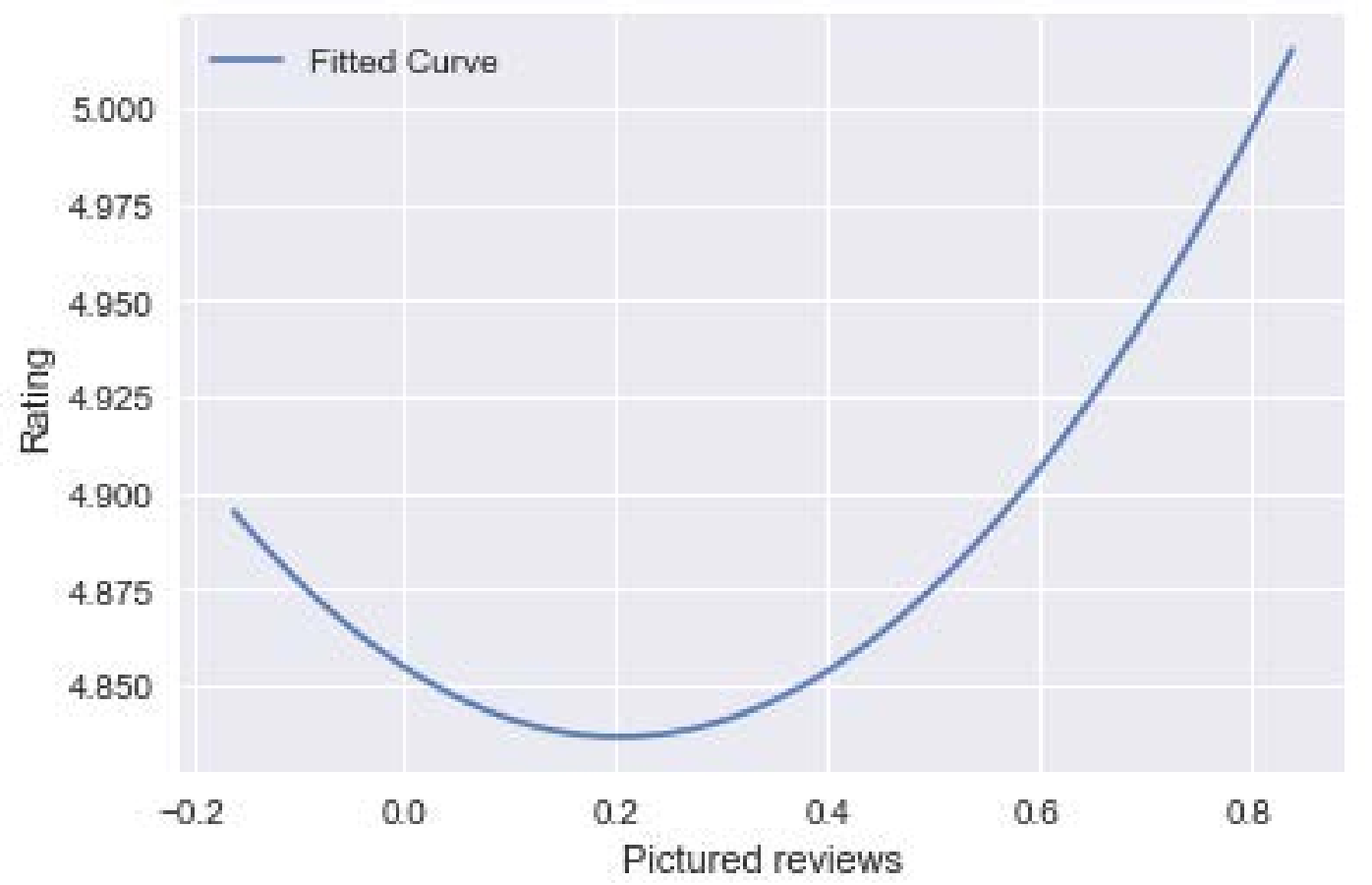

Fig. 4. Pictured reviews and online seller product rating

From the correlation result shows that reviews have a negative relation with rating ( $\mathrm{r}=-$ 0.014 ), that is: rating decreases with the increase of reviews. So, when effect 1 (high number of reviews) is greater than effect 2 (low ratio of pictured reviews) the relation tend to decrease since in the decreasing region total reviews number are very high compared to pictured reviews number, when effect 1 (low or high number of reviews) is less than effect 2 (high ratio of pictured reviews) the relation tend to increase since in the increasing region total reviews number are not high compared to pictured reviews number. Consumergenerated pictures (CGP) reflect the real information of the product. If the consumer claims with both reviews and pictures the product selling quantity will be low consequently review numbers can't be high. On the other hand, if the product is good consumers may post more pictures with the high rating, consequently increasing the selling rate and the number of reviews with the high rating. Hence if the high number of reviews with the high volume of pictured reviews exist in a product that will generate a high rating. So in overall CGP presence in the reviews improve the online seller product rating as our mentioned H1.

\subsection{Moderation effect}

\subsubsection{Product price}

We found that interaction between the pictured reviews and product price is significant $(\beta=$ $0.1181, \mathrm{p}<0.000$ ). Pictured reviews have a different effect to rating in the presence of price (See Fig. 5A). Here rating was calculated for low (1 SD below mean), med (the mean), and high (1 SD above mean) [68] of both pictured reviews and product price to fig. the moderation effect. This method is widely used to calculate the moderation effect historically. Rating increased positively for pictured reviews (low-med-high) in the presence of product 
price. Particularly we can say that for low product price pictured reviews to rating relation tend to more negative and it is increasing positively when the product price going to high. So H2a hypothesis supported as our expectation: Product price positively moderates the association between pictured reviews and ratings.
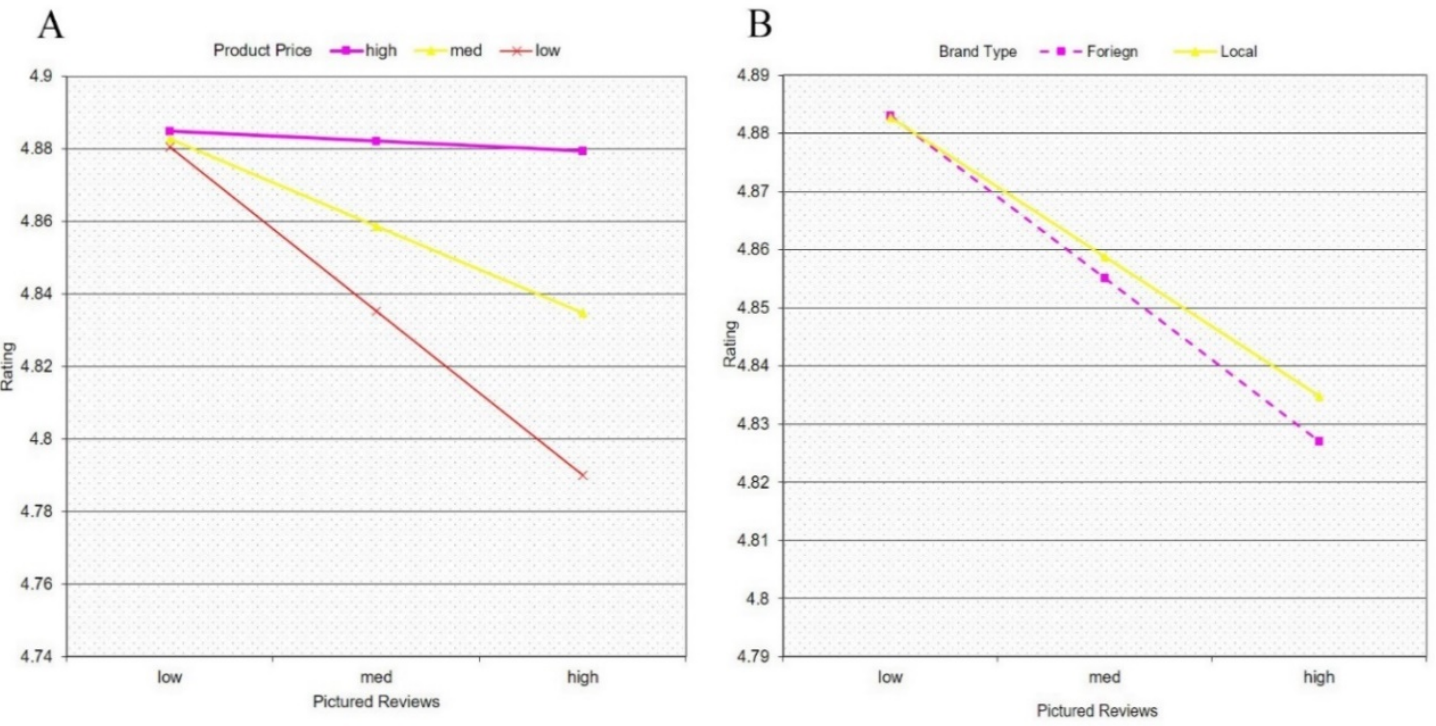

$\mathrm{C}$

D
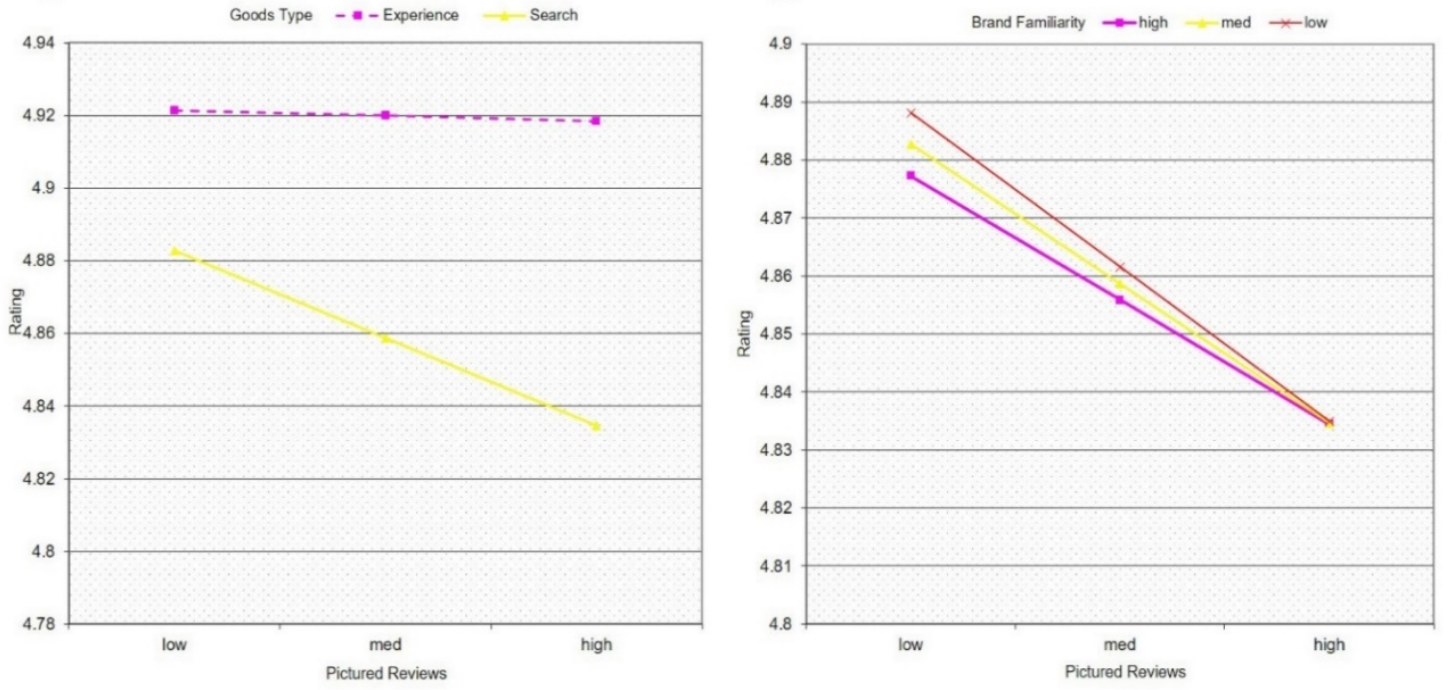

Fig. 5. Moderation effect of price, brand type, goods type and brand familiarity on pictured reviews rating

\subsubsection{Brand type (local brand vs. foreign brand)}

We noticed that interaction between the pictured reviews and brand type is also significant ( $\beta$ $=-0.0222, \mathrm{p}<0.029$ ) but less than product price. Pictured reviews have a diverse influence to rating in the presence of brand type (local brand vs. foreign brand) (See Fig. 5B). Rating increased negatively for pictured reviews (low-med-high) in the presence of brand type (local brand vs. foreign brand). Particularly we can say that, for a local brand, pictured 
reviews to rating relation tend to less negative and where for the foreign brand pictured reviews to rating relation tend to more negative. So H2b hypothesis supported as our anticipation: Foreign brand more negatively moderates the association between pictured reviews and ratings than the local brand.

\subsubsection{Goods type (search goods vs. experience goods)}

A significant interaction between the pictured reviews and goods type identified $(\beta=0.1250$, $\mathrm{p}<0.000$ ) depicting the important relation of pictured reviews and goods type. Pictured reviews reflect contrasting effect to rating in the presence of goods type (search goods vs. experience brand) (See Fig. 5C). Rating increased positively for pictured reviews (low-medhigh) in the presence of goods type. Particularly we can say that, for search goods pictured reviews to rating relation tend to more negative and where for the experience goods pictured reviews to rating relation tend to less negative and increasing to positive. So H2c hypothesis supported as our contemplation: goods type positively moderates the association between pictured reviews and ratings.

\subsubsection{Brand familiarity (not well known - well known)}

A less significant $(\beta=0.0087, p<0.010)$ value noticed for relation of pictured reviews and brand familiarity. Distinct responses of pictured reviews to rating in the presence of brand familiarity (See Fig. 5D) were noticed through the moderation effect of brand familiarity. Rating increased positively for pictured reviews (low-med-high) in the presence of brand familiarity (low-med-high). Particularly we can say that, for a less known brand, pictured reviews to rating relation tend to more negative and it is slightly increasing positively when the brand familiarity going low to high. So H2d hypothesis supported as our apprehension: brand familiarity positively moderates the association between pictured reviews and ratings.

\section{General conclusions}

With the availability of internet facilities and emerging of high-speed digital devices and technologies, more and more multimedia strategies such as seller generated video and image presentation, seller generated tiny video displaying the application of the products, consumer-generated images and videos in OCRs will be applied in the ecommerce domain to induce consumer behavior and improve the selling rate. These multimedia strategies will continue to advance rapidly with continuous evolvement in the ecommerce sector. Parallel to these multimedia strategies efficient application, it is contemporary demand to realize the underlying mechanism by which multimedia strategies influence the consumer behavior, decision-making process, and selling rate in digital commerce domain. After exploring and investigating the online seller product rating induced by the stimuli of picture presence in OCRs, this research delivers new meaningful insights into consumer psychology, decisionmaking process, online retailing, and operation management domain. Using the real OCRs data of two top popular ecommerce platforms in China which have greater reliability than previous studies, this original research article investigated the relevant influence of pictures in reviews to online seller product rating. Our study particularly delineates that picture presence in reviews improves the online seller product rating. Seller product rating is one of the key concern of both consumer and seller. This rating reflects the holistic meaning of the retailer's parameters such as loyalty, trust, quality, service level, and price premium. Thus by improving the rating, retailers passively improving their all parameters with selling rate. 


\subsection{Theoretical implications}

The outcomes of this research afford the pragmatic support for Dual Coding Theory (DCT) in the context of ecommerce. Pictures presence in OCRs as a stimulus that influences how consumer react to the online seller product rating in the context of ecommerce environment $[11,69]$. Following and supporting the DCT as one of the seminal information processing theory in the context of search and experience goods in ecommerce, this research discovered that consumer-generated pictures as visual stimuli activate imagery processing in parallel with the textual reviews as verbal representations [43]. It also proves that pictures in OCRs as additional influences of imagery and verbal processing are more influential than only textual reviews as verbal code [48].

The observations of this study prominently extend the existing literature about online consumer reviews (OCRs). Our empirical study provides two important contributions to the field of OCRs. First, whereas previous research focused on OCRs comprehension, assessment, readability, sentiments, understandability, performance [20, 30, 54, 70] and trust, consumer behavior, purchasing intention, consumer e-loyalty based on OCRs [36, 71] this effortful study investigates the influence of picture existence in reviews to ratings for the product in online shopping. Especially prior research concerning few contributions about the picture influence to rating in the OCRs area.

Second, prior research focused on OCRs helpfulness, consumer behavior on OCRs, digital product presentation based on product type (search and experience goods) [61]. But only few research shows contribution about moderation effect on pictured reviews to seller product rating by the interaction of product price, brand type (local vs. foreign brand), brand familiarity (not well known - well known) and goods type (search vs. experience goods). This extensive research observes the moderation effect of relevant variables such as product price, brand type (local vs. foreign), brand familiarity (not well known -well known), and goods type (search vs. experience). A quadratic effect of pictured reviews also observed as the moderation role. Significant relation of pictured reviews with product price, brand type (local vs. foreign), brand familiarity (not well known -well known), and goods type (search vs. experience) was noticed and their moderation effect to the relation of pictured reviews and rating also fig.d through results section.

\subsection{Managerial implications}

In addition to the contributions of research on ecommerce, our study also offers important implications for practitioners, online retailers, marketplace vendor, and manufacturer. Influence of picture presence in reviews to rating is an ambiguous and opaque term to researchers and retailers where they are yet to hesitate about picture presence advantage or disadvantage and sentiments of CGP in OCRs. Our fruitful research delineates that picture presence in reviews improve the rating which can increase the awareness of picture influence to rating, consequently increasing the selling rate and trust of online retailer and reducing the ambiguity about picture influence. With the advantages of information technology, online selling competition becomes furious and strategic. More sellers and online marketplaces are striving to increase OCR elements in various display technic. Through the information availability, consumers can easily obtain the product information from online by a click of matter. Furthermore, several pieces of research have shown that OCRs are the more reliable source of product information than seller created information in the online marketplace. Effects of OCRs are ubiquitous in the ecommerce area, through various ways they are helpful to consumers, retailers, and vendors. OCRs greatly affect online consumer 
purchasing behavior, trust, helpfulness. Furthermore, it is beneficial for the manufacturer. Nowadays some manufacturers potentially depend on social media and OCRs as a tool to market their product and reputation. Hence, online consumer reviews, rating, and their interaction are the crucial demand for both online retailers, vendors, and marketplace owners. Online seller/retailers can take the advantages of picture presence in the consumer reviews to improve their selling rate and reputation as a sense of consumer trust. They can attract more buyer by consumer-generated pictures (CGP) and information as evidence of their service, support, and product quality. Online retailers can use the CGP in the reviews as a tool of product application and features. Marketplace owner can take the advantages of pictures as quality control of their seller. They can get enough proof and evidence about the quality of the seller product by the CGP in the reviews. On the contrary, they can use CGP as a marketing tool to for their marketplace. A manufacturer also can get the advantages from CGP. Some seller may sell the fake product and refurbished product by the name of one popular brand, so the manufacturer can trace this CGP to get the proper information about how the online seller product sales and quality of their product. Conversely, more CGP will increase their brand reputation and marketing.

\subsection{Limitation and Future research}

This study features some limitations. We collected data displayed in both jd.com and Taobao.com for the total quantity of reviews and pictured reviews but we cannot guarantee these data are accurate. Since we cannot get reviews more than 2000 for reviews of the individual product on both platforms. So we were unable to cross-check the data accuracy due to invisibility of full reviews set. Future research can be done where the complete set of individual reviews are visible or simulation-based pictured reviews to see the pictured reviews relations to the rating. Nowadays OCRs are the active research area especially for marketing, retailing, consumer behavior, trust and so on. More and more researcher focusing their research on OCRs by numerous technique such as regression analysis, fsQCA, metaanalysis, Monte- Carlo, SEM, data mining approach etc. Considering pictured reviews importance to the seller, vendor, manufacturer we recommend future research on the following directions: (1) our research is based on cross-sectional data, so researcher may find the pictured reviews effect to rating for longitudinal (panel) data, (2) this research find the pictured reviews and rating relation of one product link that is overall rating for one product, we didn't research for every review, so researcher may find the pictured reviews and rating relations for every review generated by consumer, (3) find the trustworthiness and purchasing decision relation based on pictured reviews, (4) for the marketing practitioners, they may find the pictured reviews effect on selling rate, (5) for the data mining researcher they can find the fake comments the comments by considering pictured reviews as a new degree of data. Such kind of extensive research can be helpful for managerial implications and can advance the new explanation of pictures to rating relationship.

\section{Acknowledgments}

The work described in this paper was partially supported by grants from the National Natural Science Foundation of China (No. 71531003, No. 71432003, No. 71772025, No.71772026, No. 71571029). 


\section{References}

[1] Statista, "How customers decide whether to buy from your website," https://www.statista.com/statistics/379046/worldwide-retail-e-commerce-sales/, 2018. Article (CrossRef Link).

[2] Y. J. Kim, and A. B. Hollingshead, "Online social influence: Past, present, and future," Annals of the International Communication Association, vol. 39, no. 1, pp. 163-192, 2015.

Article (CrossRef Link).

[3] P. Huang, N. H. Lurie, and S. Mitra, "Searching for experience on the web: an empirical examination of consumer behavior for search and experience goods," Journal of $m$ arketing, vol. 73, no. 2, pp. 55-69, 2009. Article (CrossRef Link).

[4] S. Hong, and H. S. Park, "Computer-mediated persuasion in online reviews: Statistical versus narrative evidence," Computers in Human Behavior, vol. 28, no. 3, pp. 906-919, 2012. Article (CrossRef Link).

[5] N. Amblee, and T. Bui, "Harnessing the influence of social proof in online shopping: The effect of electronic word of mouth on sales of digital microproducts," International Journal of Electronic Commerce, vol. 16, no. 2, pp. 91-114, 2011. Article (CrossRef Link).

[6] J. Nielsen, "State of the media: the social media report," Nielsen Company, http://blog. nielsen. com/nielsenwire/social, 2011. Article (CrossRef Link).

[7] A. Lipsman, "Online consumer-generated reviews have significant impact on offline purchase behavior,” comScore, Inc. Industry Analysis, pp. 2-28, 2007. Article (CrossRef Link).

[8] S. G. Moore, "Some things are better left unsaid: how word of mouth influences the storyteller," Journal of Consumer Research, vol. 38, no. 6, pp. 1140-1154, 2011. Article (CrossRef Link).

[9] S. S. Song, and M. Kim, "Does more mean better? An examination of visual product presentation in e-retailing," Journal of Electronic Commerce Research, vol. 13, no. 4, pp. 345-355, 2012. Article (CrossRef Link).

[10] M. Kim, and S. Lennon, "The effects of visual and verbal information on attitudes and purchase intentions in internet shopping,” Psychology \& Marketing, vol. 25, no. 2, pp. 146-178, 2008. Article (CrossRef Link).

[11] J.-H. Kim, M. Kim, and S. J. Lennon, "Effects of web site atmospherics on consumer responses: music and product presentation,” Direct Marketing: An International Journal, vol. 3, no. 1, pp. 4-19, 2009. Article (CrossRef Link).

[12] J. Kim, and S. Forsythe, "Sensory enabling technology acceptance model (SE - TAM): A multiple - group structural model comparison,” Psychology \& Marketing, vol. 25, no. 9, pp. 901922, 2008. Article (CrossRef Link).

[13] K. J. Kim, and S. S. Sundar, "Mobile persuasion: Can screen size and presentation mode make a difference to trust?," Human Communication Research, vol. 42, no. 1, pp. 45-70, 2016. Article (CrossRef Link).

[14] E. Beuckels, and L. Hudders, "An experimental study to investigate the impact of image interactivity on the perception of luxury in an online shopping context," Journal of Retailing and Consumer Services, vol. 33, pp. 135-142, 2016. Article (CrossRef Link).

[15] E. Maier, and F. Dost, "The positive effect of contextual image backgrounds on fluency and liking,” Journal of Retailing and Consumer Services, vol. 40, pp. 109-116, 2018. Article (CrossRef Link).

[16] C. Dellarocas, "The digitization of word of mouth: Promise and challenges of online feedback mechanisms," Management science, vol. 49, no. 10, pp. 1407-1424, 2003. Article (CrossRef Link).

[17] D. Godes, and D. Mayzlin, "Using online conversations to study word-of-mouth communication," Marketing science, vol. 23, no. 4, pp. 469-631, 2004. Article (CrossRef Link).

[18] J. A. Chevalier, and D. Mayzlin, "The effect of word of mouth on sales: Online book reviews," Journal of marketing research, vol. 43, no. 3, pp. 345-354, 2006. Article (CrossRef Link).

[19] X. Li, and L. M. Hitt, "Self-selection and information role of online product reviews," Information Systems Research, vol. 19, no. 4, pp. 456-474, 2008. Article (CrossRef Link). 
[20] N. Hu, I. Bose, N. S. Koh, and L. Liu, "Manipulation of online reviews: An analysis of ratings, readability, and sentiments,” Decision Support Systems, vol. 52, no. 3, pp. 674-684, 2012. Article (CrossRef Link).

[21] Z. Zhang, Q. Ye, R. Law, and Y. Li, “The impact of e-word-of-mouth on the online popularity of restaurants: A comparison of consumer reviews and editor reviews," International Journal of Hospitality Management, vol. 29, no. 4, pp. 694-700, 2010. Article (CrossRef Link).

[22] L. M. Willemsen, P. C. Neijens, F. Bronner, and J. A. De Ridder, ““Highly recommended!” The content characteristics and perceived usefulness of online consumer reviews," Journal of Computer-Mediated Communication, vol. 17, no. 1, pp. 19-38, 2011. Article (CrossRef Link).

[23] Y. Chen, and J. Xie, "Online consumer review: Word-of-mouth as a new element of marketing communication mix,” Management science, vol. 54, no. 3, pp. 477-491, 2008.

Article (CrossRef Link).

[24] Z. Yang, and X. Fang, "Online service quality dimensions and their relationships with satisfaction: A content analysis of customer reviews of securities brokerage services," International Journal of Service Industry Management, vol. 15, no. 3, pp. 302-326, 2004.

Article (CrossRef Link).

[25] E. K. Clemons, and G. G. Gao, "Consumer informedness and diverse consumer purchasing behaviors: Traditional mass-market, trading down, and trading out into the long tail," Electronic Commerce Research and Applications, vol. 7, no. 1, pp. 3-17, 2008. Article (CrossRef Link).

[26] N. Hu, L. Liu, and J. J. Zhang, "Do online reviews affect product sales? The role of reviewer characteristics and temporal effects,” Information Technology and Management, vol. 9, no. 3, pp. 201-214, 2008. Article (CrossRef Link).

[27] S. M. Mudambi, and D. Schuff, "Research note: What makes a helpful online review? A study of customer reviews on Amazon. com,” MIS quarterly, vol. 34, no. 1, pp. 185-200, 2010. Article (CrossRef Link).

[28] Q. Cao, W. Duan, and Q. Gan, "Exploring determinants of voting for the "helpfulness" of online user reviews: A text mining approach,” Decision Support Systems, vol. 50, no. 2, pp. 511-521, 2011. Article (CrossRef Link).

[29] N. Korfiatis, E. GarcíA-Bariocanal, and S. SáNchez-Alonso, "Evaluating content quality and helpfulness of online product reviews: The interplay of review helpfulness vs. review content," Electronic Commerce Research and Applications, vol. 11, no. 3, pp. 205-217, 2012. Article (CrossRef Link).

[30] E.-J. Lee, and S. Y. Shin, "When do consumers buy online product reviews? Effects of review quality, product type, and reviewer's photo," Computers in Human Behavior, vol. 31, pp. 356366, 2014. Article (CrossRef Link).

[31] A. H. Huang, K. Chen, D. C. Yen, and T. P. Tran, "A study of factors that contribute to online review helpfulness,” Computers in Human Behavior, vol. 48, pp. 17-27, 2015. Article (CrossRef Link).

[32] A. Qazi, K. B. S. Syed, R. G. Raj, E. Cambria, M. Tahir, and D. Alghazzawi, “A concept-level approach to the analysis of online review helpfulness," Computers in Human Behavior, vol. 58, pp. 75-81, 2016. Article (CrossRef Link).

[33] Q. Zhou, R. Xia, and C. Zhang, “Online shopping behavior study based on multi-granularity opinion mining: China versus America,” Cognitive Computation, vol. 8, no. 4, pp. 587-602, 2016. Article (CrossRef Link).

[34] A. Munzel, "Assisting consumers in detecting fake reviews: The role of identity information disclosure and consensus,” Journal of Retailing and Consumer Services, vol. 32, pp. 96-108, 2016. Article (CrossRef Link).

[35] Y. Huang, C. Li, J. Wu, and Z. Lin, “Online customer reviews and consumer evaluation: The role of review font,” Information \& Management, vol. 55, no. 4, pp. 430-440, 2018. Article (CrossRef Link).

[36] D. Gavilan, M. Avello, and G. Martinez-Navarro, "The influence of online ratings and reviews on hotel booking consideration,” Tourism Management, vol. 66, pp. 53-61, 2018. Article (CrossRef Link). 
[37] M. Kim, "Digital product presentation, information processing, need for cognition and behavioral intent in digital commerce,” Journal of Retailing and Consumer Services, vol. 50, pp. 362-370, 2019. Article (CrossRef Link).

[38] E. W. Anderson, “Customer satisfaction and word of mouth,” Journal of service research, vol. 1, no. 1, pp. 5-17, 1998. Article (CrossRef Link).

[39] S. Aral, and D. Walker, "Identifying influential and susceptible members of social networks," Science, vol. 337, no. 6092, pp. 337-341, 2012. Article (CrossRef Link).

[40] K. M. Hunt, “Gaming the system: Fake online reviews v. consumer law," Computer Law \& Security Review, vol. 31, no. 1, pp. 3-25, 2015. Article (CrossRef Link).

[41] C. Delp, and J. Jones, "Communicating information to patients: the use of cartoon illustrations to improve comprehension of instructions,” Academic Emergency Medicine, vol. 3, no. 3, pp. 264270, 1996. Article (CrossRef Link).

[42] J. Riegelsberger, M. A. Sasse, and J. D. McCarthy, "Shiny happy people building trust?: photos on e-commerce websites and consumer trust," pp. 121-128, 2003. Article (CrossRef Link).

[43] A. Paivio, "Imagery and verbal processes. Holt, Rinehart and Winston.[GVJ](1983) The empirical case for dual coding," Imagery, memory and cognition, ed. JC Yuille. Erlbaum.[GVJ], 1971.

[44] A. Paivio, Mental representations: A dual coding approach, Oxford University Press, 1990. Article (CrossRef Link).

[45] B. J. O'Neill, "Defineability as an index of word meaning,” Journal of Psycholinguistic Research, vol. 1, no. 4, pp. 287-298, 1972. Article (CrossRef Link).

[46] M. Denis, "Imagery and prose: A critical review of research on adults and children," TextInterdisciplinary Journal for the Study of Discourse, vol. 4, no. 4, pp. 381-402, 1984. Article (CrossRef Link).

[47] J. M. Clark, and A. Paivio, "Dual coding theory and education,” Educational psychology review, vol. 3, no. 3, pp. 149-210, 1991. Article (CrossRef Link).

[48] A. Paivio, "Coding distinctions and repetition effects in memory," The psychology of learning and motivation, vol. 9, pp. 179-214, 1975. Article (CrossRef Link).

[49] A. Paivio, "Mental imagery in associative learning and memory," Psychological review, vol. 76, no. 3, pp. 241-263, 1969. Article (CrossRef Link).

[50] C. E. Weinstein, v. L. Underwood, F. W. Wicker, and W. E. Cubberly, "Cognitive learning strategies: Verbal and imaginal elaboration,” Cognitive and affective learning strategies, pp. 4575, 1979.

[51] D. Weathers, S. Sharma, and S. L. Wood, "Effects of online communication practices on consumer perceptions of performance uncertainty for search and experience goods," Journal of retailing, vol. 83, no. 4, pp. 393-401, 2007. Article (CrossRef Link).

[52] P. Nelson, “Information and consumer behavior,” Journal of political economy, vol. 78, no. 2, pp. 311-329, 1970. Article (CrossRef Link).

[53] L. R. Klein, "Evaluating the potential of interactive media through a new lens: Search versus experience goods,” Journal of business research, vol. 41, no. 3, pp. 195-203, 1998. Article (CrossRef Link).

[54] L. Huang, C.-H. Tan, W. Ke, and K.-K. Wei, "Comprehension and assessment of product reviews: A review-product congruity proposition,” Journal of Management Information Systems, vol. 30, no. 3, pp. 311-343, 2013. Article (CrossRef Link).

[55] K. Z. Zhang, C. M. Cheung, and M. K. Lee, "Examining the moderating effect of inconsistent reviews and its gender differences on consumers' online shopping decision,” International Journal of Information Management, vol. 34, no. 2, pp. 89-98, 2014. Article (CrossRef Link).

[56] L.-T. Bei, E. Y. Chen, and R. Widdows, "Consumers' online information search behavior and the phenomenon of search vs. experience products,” Journal of Family and Economic Issues, vol. 25, no. 4, pp. 449-467, 2004. Article (CrossRef Link).

[57] Statista, "Market share of B2C online shopping websites in China in 2nd quarter 2017," https://www.statista.com/statistics/323115/market-share-of-b2c-online-retailers-in-china/, 2017. Article (CrossRef Link). 
[58] eMarketerRETAIL, “Alibaba's Tmall Maintains Reign Over China's Retail Ecommerce,” 201702-21, 2017. Article (CrossRef Link).

[59] S. Reuters, China, “Alibaba Singles' Day sales race past \$5 bln in first hour,” 2016-11-11, 2016. Article (CrossRef Link).

[60] iResearch, “2018 China's 618 Shopping Festival Report,” July 04, 2018, 2018. Article (CrossRef Link).

[61] J. Luan, Z. Yao, F. Zhao, and H. Liu, "Search product and experience product online reviews: an eye-tracking study on consumers' review search behavior,” Computers in Human Behavior, vol. 65, pp. 420-430, 2016. Article (CrossRef Link).

[62] R. M. Baron, and D. A. Kenny, "The moderator-mediator variable distinction in social psychological research: Conceptual, strategic, and statistical considerations," Journal of personality and social psychology, vol. 51, no. 6, pp. 1173-1182, 1986. Article (CrossRef Link).

[63] J. Cohen, P. Cohen, S. G. West, and L. S. Aiken, Applied multiple regression/correlation analysis for the behavioral sciences, Routledge, 2013. Article (CrossRef Link).

[64] R. R. Wilcox, Applying contemporary statistical techniques, Academic Press, 2003. Article (CrossRef Link).

[65] R. Andersen, Modern methods for robust regression, Sage, 2008. Article (CrossRef Link).

[66] A. F. Hayes, Introduction to mediation, moderation, and conditional process analysis: A regression-based approach, Guilford Publications, 2017. Article (CrossRef Link).

[67] F. Zhu, and X. Zhang, "Impact of online consumer reviews on sales: The moderating role of product and consumer characteristics,” Journal of marketing, vol. 74, no. 2, pp. 133-148, 2010.

[68] L. S. Aiken, S. G. West, and R. R. Reno, Multiple regression: Testing and interpreting interactions, Sage, 1991. Article (CrossRef Link).

[69] M.-O. Richard, and J.-C. Chebat, "Modeling online consumer behavior: Preeminence of emotions and moderating influences of need for cognition and optimal stimulation level," Journal of Business Research, vol. 69, no. 2, pp. 541-553, 2016. Article (CrossRef Link).

[70] M. Salehan, and D. J. Kim, "Predicting the performance of online consumer reviews: A sentiment mining approach to big data analytics,” Decision Support Systems, vol. 81, pp. 30-40, 2016. Article (CrossRef Link).

[71] J. Fang, Y. Shao, and C. Wen, "Transactional quality, relational quality, and consumer e-loyalty: Evidence from SEM and fsQCA,” International Journal of Information Management, vol. 36, no. 6, pp. 1205-1217, 2016. Article (CrossRef Link). 


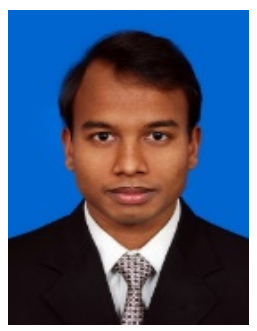

Md Altab Hossin received MSc from University of Electronic Science and Technology of China. Currently, he is working as a Ph.D. degree candidate at the School of Management and Economics, University of Electronic Science and Technology of China (UESTC). His research interests include E-Business, Information Systems \& Management, Big Data, and Consumer Behavior.

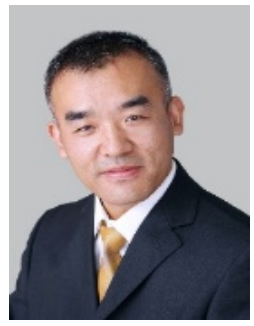

Yinping Mu is Professor of Information Management and E-Business at the University of Electronic Science and Technology of China (UESTC). His research interests include ecommerce and social commerce, and operations management. His work has appeared in several EC and operations management journals.

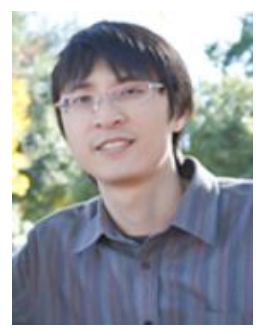

Jiaming Fang is an Associate Professor of Information Management and E-Business at the University of Electronic Science and Technology of China (UESTC). His research interests include electronic commerce and social commerce, data mining, and humancentered computation. His work has appeared in several EC and information management journals.

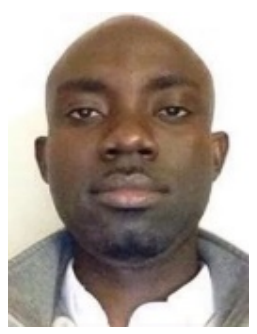

Adasa Nkrumah Kofi Frimpong holds Master degree from FHNW Switzerland (MSc Business Information System). He is currently a Ph.D. Student at the School of Management and Economics, University of Electronic Science and Technology of China. His research interests include E-Business and Data Mining. 